\title{
A new cochliodont anterior tooth plate from the Mississippian of Alabama (USA) having implications for the origin of tooth plates from tooth files
}

Wayne M. Itano ${ }^{1 *}$ id and Lance L. Lambert ${ }^{2}$

\begin{abstract}
Background: Paleozoic holocephalian tooth plates are rarely found articulated in their original positions. When they are found isolated, it is difficult to associate the small, anterior tooth plates with the larger, more posterior ones. Tooth plates are presumed to have evolved from fusion of tooth files. However, there is little fossil evidence for this hypothesis.

Results: We report a tooth plate having nearly perfect bilateral symmetry from the Mississippian (Chesterian Stage) Bangor Limestone of Franklin County, Alabama, USA. The high degree of symmetry suggests that it may have occupied a symphyseal or parasymphyseal position. The tooth plate resembles Deltodopsis? bialveatus St. John and Worthen, 1883, but differs in having a sharp ridge with multiple cusps arranged along the occlusal surface of the presumed labiolingual axis, rather than a relatively smooth occlusal surface. The multicusped shape is suggestive of a fused tooth file. The middle to latest Chesterian (Serpukhovian) age is determined by conodonts found in the same bed.

Conclusion: The new tooth plate is interpreted as an anterior tooth plate of a chondrichthyan fish. It is referred to Arcuodus multicuspidatus Itano and Lambert, gen. et sp. nov. Deltodopsis? bialveatus is also referred to Arcuodus.
\end{abstract}

Keywords: Chondrichthyes, Cochliodontiformes, Carboniferous, Mississippian, Bangor limestone, Alabama, Conodonts

\section{Background}

Extant chondrichthyan fishes comprise two clades: the elasmobranchs (sharks, skates, and rays) and the holocephalians (chimaeras). Extant holocephalians possess a dentition consisting of three pairs of tooth plates, a large pair in the mandible and two pairs in the palate [1]. The elasmobranch arrangement of teeth, consisting of rows of tooth files, is thought to be plesiomorphic for crown-group chondrichthyans. Some early holocephalians, e.g., Helodus, had a dentition consisting partially of tooth files [2].

Recently, tooth pattern formation in extant elasmobranchs has been studied in great detail, including studies of its embryonic development and gene expression [3-5].

\footnotetext{
* Correspondence: Wayne.Itano@aya.yale.edu

1 Museum of Natural History, University of Colorado, Boulder, CO 80309, USA Full list of author information is available at the end of the article
}

Paleontological studies show that the elasmobranch dental pattern of rows of tooth files, with teeth replaced in a linguo-labial sequence has been highly conserved, since it appears in the early stem-chondrichthyan Doliodus problematicus (Emsian, Early Devonian, about $397 \mathrm{Ma}$ ) [6]. Comparatively little investigation of tooth plate development in extant holocephalians has been made to date.

How and when the transition from tooth files to tooth plates in holocephalians took place is poorly understood. The age of the most recent common ancestor of modern elasmobranchs and holocephalians has been estimated, by a molecular clock method based on mitogenomic sequences, to be late Silurian, about $421 \mathrm{Ma}$ [7]. Fossil evidence places the date of divergence between the two clades to be no later than the late Carboniferous (Pennsylvanian) [8] or the latest Devonian [9]. Due to

(c) The Author(s). 2018 Open Access This article is distributed under the terms of the Creative Commons Attribution 4.0 International License (http://creativecommons.org/licenses/by/4.0/), which permits unrestricted use, distribution, and 
the poor fossil record of holocephalians following the end-Permian extinctions, it is not known from which group of Paleozoic holocephalians the extant chimaeroids are descended. Recent studies of tooth plates of the extant holocephalian Callorhinchus milii have found that each tooth plate is of a compound nature, representing the fusion of two teeth from a reduced tooth file [1]. Studies of the transition from tooth files to tooth plates are of interest in their own right. They also have the potential of helping to elucidate the phylogeny of the extant holocephalians, particularly when combined with the study of the ontogeny of tooth plates of extant holocephalians.

A holocephalian tooth plate of unusual morphology was recently found in the late Mississippian (early Carboniferous) Bangor Limestone of northern Alabama, USA. An abstract has been published previously [10]. Chondrichthyan remains from the Mississippian of northern Alabama have been reviewed recently [11]. The holocephalian taxa reported from the Bangor Limestone are: Deltodus sp. cf. D. undulatus, Helodus crenulatis, and Psammodus sp.

Fossil tooth plates of holocephalian chondrichthyan fishes are usually found isolated from each other and from other remains. Isolated tooth plates have been classified into species, genera, families, and higher taxonomic categories based on morphology, but their true phylogenetic relationships are often uncertain. Undoubtedly, tooth plates from different positions within the dentitions of the same fishes have been given distinct specific or even generic names. As closely associated or articulated remains are found, some of these genera or species will become junior synonyms of others. There seems to be no reasonable alternative to this somewhat awkward procedure, but it has worked well over time in a similar manner with the multi-element feeding apparatuses of conodonts. The most complete guide to holocephalian fishes is the monograph of Stahl [2]. Only a small fraction of the species listed in that monograph are known from articulated or associated remains.

Among the rare articulated and associated remains are the following: (1) Largely complete single-jaw dentitions of the Mississippian cochliodontiform fishes Cochliodus contortus and Streblodus oblongus have been reported [12]. It has been proposed that they represent the mandibular and palatal dentitions, respectively, of the same species [12]. However, the association has not been verified directly. (2) Three pairs of tooth plates, from the Pennsylvanian of Ohio, USA, apparently belonging to the same fish, have been found in close association [13]. The two large plates presumed to be mandibular were previously described as Deltodus angularis, the two large plates presumed to be palatal, as Sandalodus carbonarius, and two small plates presumed to be anterior mandibular, as Orthopleurodus carbonarius.
Anterior tooth plates of holocephalians are even less well understood than the posterior ones. Being small, they are less likely to be preserved or collected. Apparently none of the articulated Cochliodus contortus or Streblodus oblongus dentitions preserve the teeth or tooth plates of the extreme anterior region. One of the few holocephalian dentitions preserved with all of the anterior tooth plates in their original positions is that of Harpagofututor volsellorhinus, from the Chesterian (Serpukhovian) Bear Gulch Limestone of Montana, USA [14]. Fig. 1 shows thecorrelation between the standard subdivisions of the Carboniferous Period (e.g., Serpukhovian) and the North American regional subdivisions (e.g., Chesterian). The data are taken from ([15], fig. 23.1). H. volsellorhinus has three anterior tooth plates (one symphyseal and two parasymphyseal) in the lower jaw and two (parasymphyseal) in the upper jaw. The dentition of another Mississippian holocephalian, Chondrenchelys problematica (Order Chondrenchelyformes), has been described recently $[16,17]$. In addition to possessing sets of tooth plates in the upper and lower jaws, not too dissimilar to those of Mesozoic and Cenozoic holocephalians, C. problematica possesses sets of extramandibular teeth arranged around the periphery of the anterior end of the mouth. This condition is not known in any other chondrichthyan. If found isolated, these anterior teeth would have been identified as those of petalodonts (Order Petalodoniformes). This example illustrates the difficulty of determining whether isolated teeth or tooth plates belong to the same species, as well as the difficulty of identifying isolated chondrichthyan teeth or tooth plates, even to the level of order.

Holocephalian tooth plates are presumed to have evolved by fusion of tooth files. However, there is little fossil evidence for this hypothesis. The dentition of Helodus simplex Agassiz, 1838 [18], the type species of Helodus, includes both tooth files and tooth plates [19]. Figure 2 shows a tooth file of Helodus simplex. The tooth plates in the dentition of Helodus have corrugated outlines, which may be remnants of their origin from separate teeth. Isolated tooth plates of this form have been given the genus name Pleuroplax. Figure 3 shows a tooth plate of Pleuroplax rankinei. Both $H$. simplex and $P$. rankinei are known from articulated remains $[19,20]$. These remains show that the two species have a close relationship, but the dentition of $P$. rankinei appears to consist entirely of tooth plates, while that of $H$. simplex includes both tooth files and tooth plates. The anterior tooth plates of $H$. volsellorhinus display longitudinal ridges with bumps that "distinctly resemble fused teeth" [14].

The morphology of the recently-found tooth plate from the Bangor Limestone suggests that it could shed some light on (1) the nature of anterior holocephalian dentitions and (2) on the transition from tooth files to tooth plates. 


\begin{tabular}{|c|c|c|c|}
\hline $\begin{array}{l}\text { Age } \\
\text { (Ma) }\end{array}$ & \multicolumn{2}{|c|}{$\begin{array}{c}\text { Epoch/Age } \\
\text { (Stage) }\end{array}$} & $\begin{array}{c}\text { North } \\
\text { America } \\
\end{array}$ \\
\hline \multirow{3}{*}{300} & \multicolumn{2}{|c|}{ Permian } & Permian \\
\hline & \multirow{2}{*}{ 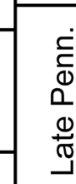 } & Gzhelian & Virgilian \\
\hline & & Kasimovian & Missourian \\
\hline \multirow[t]{2}{*}{310} & \multirow{2}{*}{$\begin{array}{l}\dot{\Sigma} \\
\overline{0} \\
0 \\
0 \\
\frac{0}{\overline{0}} \\
\frac{0}{\Sigma} \\
\end{array}$} & \multirow{2}{*}{ Moscovian } & Desmoinesian \\
\hline & & & Atakan \\
\hline \multirow[b]{2}{*}{$320-$} & $\frac{\overline{0}}{0}$ & \multirow{2}{*}{ Bashkirian } & \\
\hline & $\begin{array}{l}\text { ते } \\
\stackrel{\bar{\varpi}}{\bar{H}}\end{array}$ & & Morrowan \\
\hline \multirow[t]{2}{*}{$330-$} & 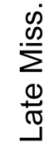 & Serpukhovian & \multirow[t]{2}{*}{ Chesterian } \\
\hline & \multirow{2}{*}{ 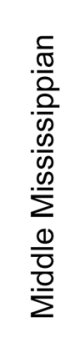 } & \multirow[b]{2}{*}{ Viséan } & \\
\hline 340 & & & Meramecian \\
\hline \multirow[t]{2}{*}{350} & \multirow{2}{*}{ 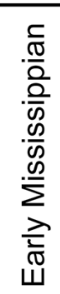 } & \multirow[b]{2}{*}{ Tournaisian } & Osagean \\
\hline & & & Kinderhookian \\
\hline 360 & \multicolumn{2}{|c|}{ Devonian } & Devonian \\
\hline
\end{tabular}

Fig. 1 Correlation of standard subdivisions of the Carboniferous Period with North American regional subdivisions. After ([15], fig. 23.1)

Locality

The tooth plate, ALMNH PV 2016.0002.0002, was found in a bed of limestone, near the shore of Little Bear Creek Reservoir, Franklin County, Alabama, USA (Fig. 4). The precise location is on file at the ALMNH and is available to qualified researchers.
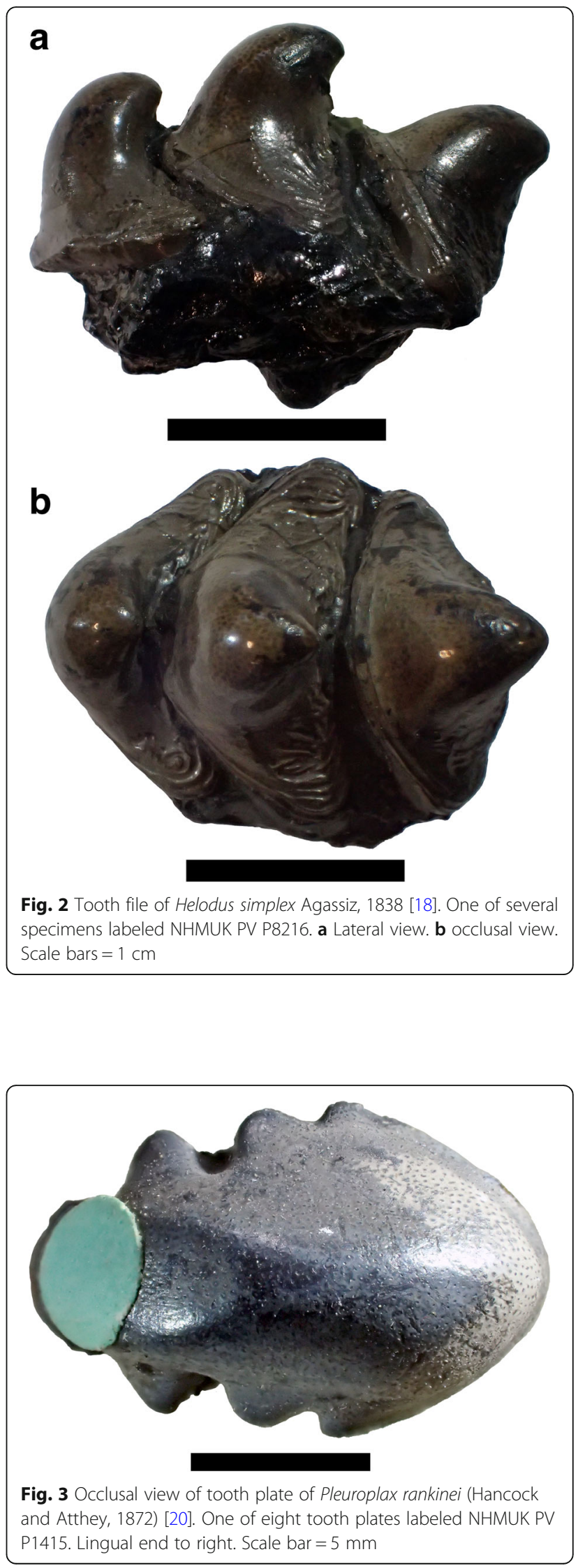

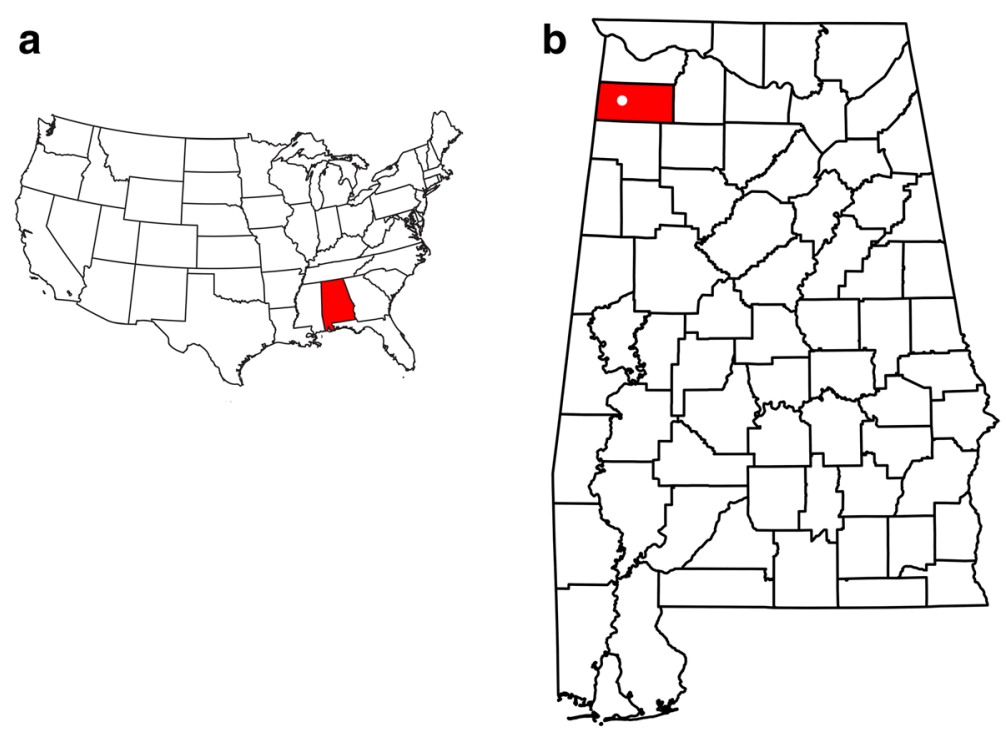

Fig. 4 a Map of the United States, with the state of Alabama outlined. b Map of Alabama with Franklin County highlighted. White dot marks location where holotype of Arcuodus multicuspidatus was found

\section{Methods}

The piece of matrix containing the tooth plate was immersed in a $5 \%$ solution of acetic acid. After 2 days, the fossil was released from the matrix. The acetic acid solution was changed several times during the 2 days. No further preparation was necessary.

Since biostratigraphically useful macrofossils, such as blastoids or crinoids, were not found in the bed, limestone matrix was processed for conodonts by standard acidization methods (e.g., [21]). Approximately $2 \mathrm{~kg}$ of limestone matrix were broken into centimeter-sized pieces and immersed in a $15 \%$ solution of formic acid for $24 \mathrm{~h}$. The insoluble residues were then wet-sieved through 850 and $125 \mu \mathrm{m}$ screens. Once dried, the residue from the $125 \mu \mathrm{m}$ screen was picked by hand for conodonts using a 000 brush under a binocular microscope.

\section{Results}

\section{Conodont biostratigraphy}

The bed in which the tooth plate was found lies within the Bangor Limestone, which is Chesterian (early Carboniferous = Mississippian) in age [22-25]. The Bangor Limestone in Franklin County is approximately $150 \mathrm{~m}$ thick [23]. The bed in which the tooth plate was found is an indurated, medium-gray, bioclastic grainstone. The grains are numerically dominated by crinoid ossicles, which along with abundant bryozoan fragments and a high diversity of other fossil fragment types suggest normal marine salinity. The grainstone fabric and abundant rounded grains indicate high current or wave energy in a shallow marine setting. Laterally in the same bed, the presence of prominent rugosan coral clusters indicates a heterogenous sea floor and a diverse shallow marine environment (Fig. 5).

Conodont P1 elements identified in the matrix from the bed were Cavusgnathus regularis, C. unicornis $(\alpha)$, C. unicornis ( $\beta$ ), and C. naviculus. According to [26], C. naviculus has the most restricted stratigraphic range of these conodonts. Presence of $C$. naviculus fixes the age of the bed as no earlier than Biozone 2 and no later than Biozone 4 of [26], middle to latest Chesterian North American regional stage. The combined middle and late Chesterian correlates closely with the international standard Serpukhovian Stage, which is late Mississippian (Fig. 1).

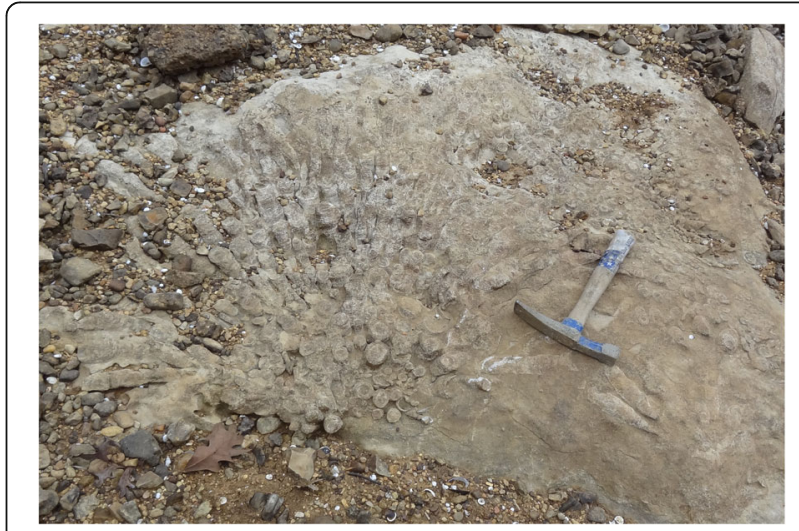

Fig. 5 Rugosan coral cluster at the type locality of Arcuodus multicuspidatus. The holotype specimen was found, displaced horizontally, at the same stratigraphic level. Rock hammer included for scale. Photograph by L. White. Used with permission 


\section{Systematic paleontology}

Chondrichthyes Huxley, 1880 [27].

Euchondrocephali Lund and Grogan, 1997 [28].

Holocephali Bonaparte, 1838 [29].

Cochliodontiformes Obruchev, 1953 [30].

Arcuodus Itano and Lambert, gen. nov., urn:Isid:zoobank.org:act:F03B0809-A0DE-475B-9E12-

\section{B3E231A319C}

\section{Etymology}

From Latin arcus $=$ arc and Greek ó $\delta$ oú $\varsigma=$ tooth

\section{Type species}

Arcuodus multicuspidatus Itano and Lambert, sp. nov.

\section{Other included species}

Deltodopsis? bialveatus St. John and Worthen, 1883 [31].

\section{Diagnosis}

Tooth plates presumed to occupy an anterior position. Elongated labiolingually, compressed laterally. Bilaterally symmetric relative to labiolingual axis or nearly so. Width and height increase lingually. Occlusal surface shows presence of tubular dentine. Smooth parts of lateral surfaces become narrow basally and have concave curvature when viewed from labial or lingual ends. Basal surface smooth and concave.

\section{Remarks}

The new genus includes some specimens assigned by St. John and Worthen [31] to their new genus Deltodopsis, with some uncertainty, such as Deltodopsis? bialveatus (Figs. 6 and 7). They did not designate a type species for

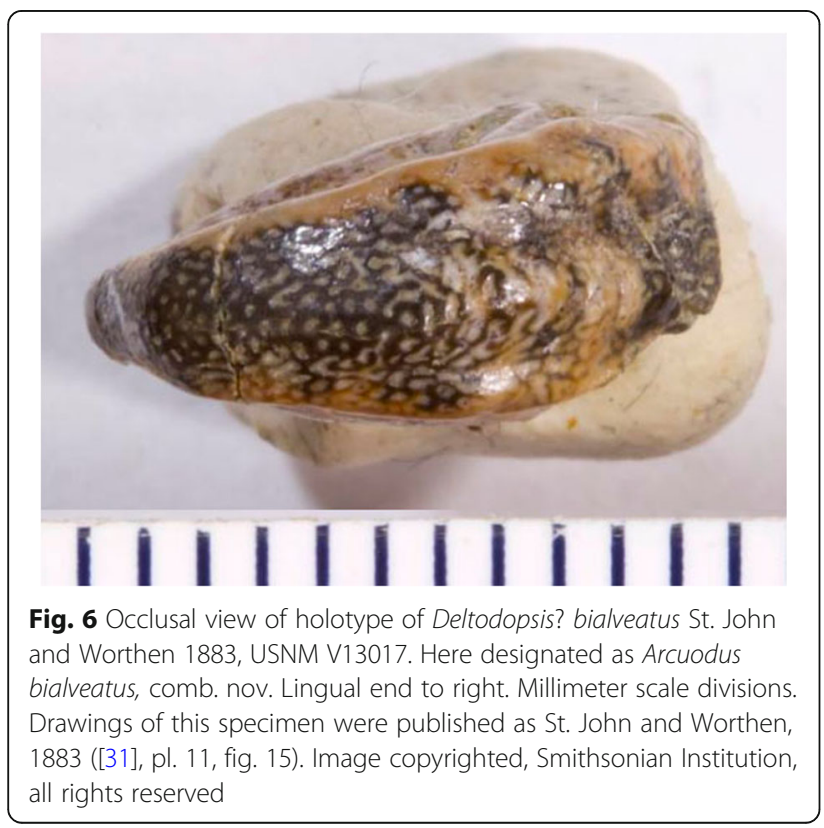

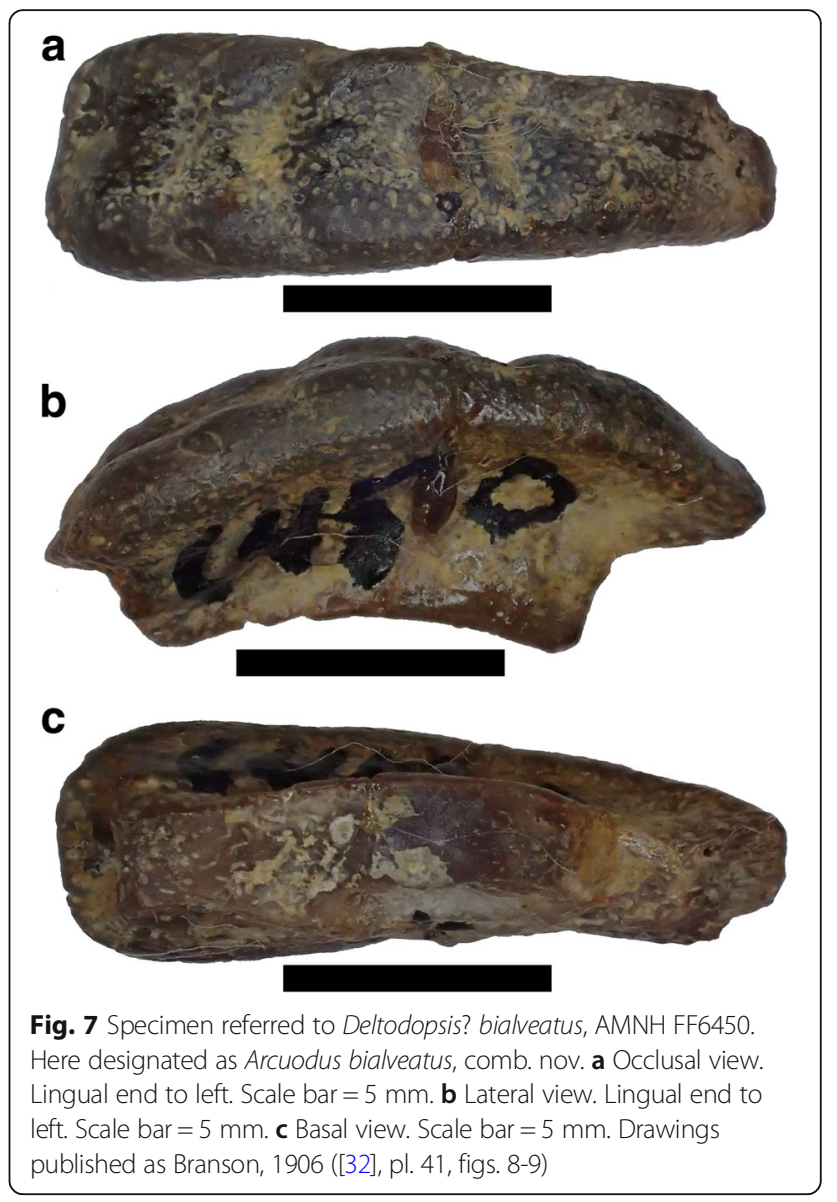

Deltodopsis. However, only the species $D$. affinis, $D$. sanctoludovici, and $D$. angustus were assigned without question to Deltodopsis. All three species are currently assigned to Deltodus, according to Stahl [2]. If this assignment is accepted, Deltodopsis is a junior synonym of Deltodus. Even if the assignment to Deltodus is not accepted, a new generic name is required for the new tooth plate (Figs. 8 and 9) and for Deltodopsis? bialveatus, since they cannot be shown definitively to belong to the same genus as Deltodopsis affinis, Deltodopsis sanctoludovici, or Deltodopsis angustus. It is likely that the tooth plates referred to Arcuodus belong to the anterior parts of the dentitions of fish for which the more posterior tooth plates have already been given generic names, such as Cochliodus. If an articulated dentition of such a fish is found, including tooth plates referable to Arcuodus and also to a previously named genus, Arcuodus would become a junior synonym of the previously named genus.

Arcuodus multicuspidatus Itano and Lambert, sp. nov., urn:Isid:zoobank.org:act:AD81711A-3B81-4219-AF6F924F47B0E1C6

Etymology

From the multiple cusps along the occlusal ridge. 


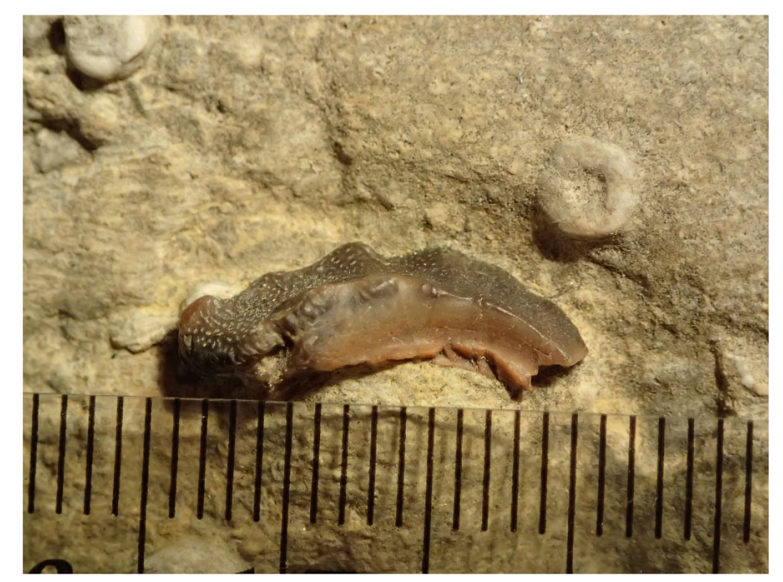

Fig. 8 Lateral view of holotype of Arcuodus multicuspidatus, Itano and Lambert, gen. et sp. nov., ALMNH PV 2016.0002.0002, prior to extraction from the matrix. Millimeter scale divisions

\section{Type locality}

Bangor Limestone, western Franklin County, Alabama, USA; middle to latest Chesterian.

\section{Holotype}

Tooth plate, ALMNH PV 2016.0002.0002.

\section{Diagnosis}

Species of Arcuodus having tooth plates in which the margin of occlusal surface forms a moderately curved, convex arc with several low cusps. When viewed from lingual or labial ends, occlusal surface appears as a sharply pointed, angular ridge. The multicusped angular ridge distinguishes it from Arcuodus bialveatus (St. John and Worthen, 1883), comb. nov., which has a more smoothly convex occlusal surface.

\section{Description}

The holotype and only known specimen is an isolated tooth plate. The labiolingual length is $15 \mathrm{~mm}$, the width is $4.5 \mathrm{~mm}$, and the height is $5.0 \mathrm{~mm}$. Unknown portions of both the lingual and labial ends are not preserved. The occlusal surface forms a sharp ridge, with six low cusps preserved. The occlusal surface shows presence of tubular dentine. Parallel vascular channels connecting to the surface pores are visible on a broken surface at the lingual end. The outline, seen in occlusal view (Fig. 9a), has a remarkable degree of bilateral symmetry. Some asymmetry can be seen in the labial view (Fig. 9c). Whether this asymmetry is normal or is pathologic is unknown.

\section{Arcuodus bialveatus (St. John and Worthen, 1883) comb.}

nov.

1883. Deltodopsis? bialveatus; St. John and Worthen [31], pp. 169-171, pl. 11, fig. 15

1883. Deltodopsis? keokuk; St. John and Worthen [31], pp. 169-171, pl. 11, fig. 16

1883. Deltodopsis? convexus; St. John and Worthen [31], pp. 169-171, pl. 11, fig. 17
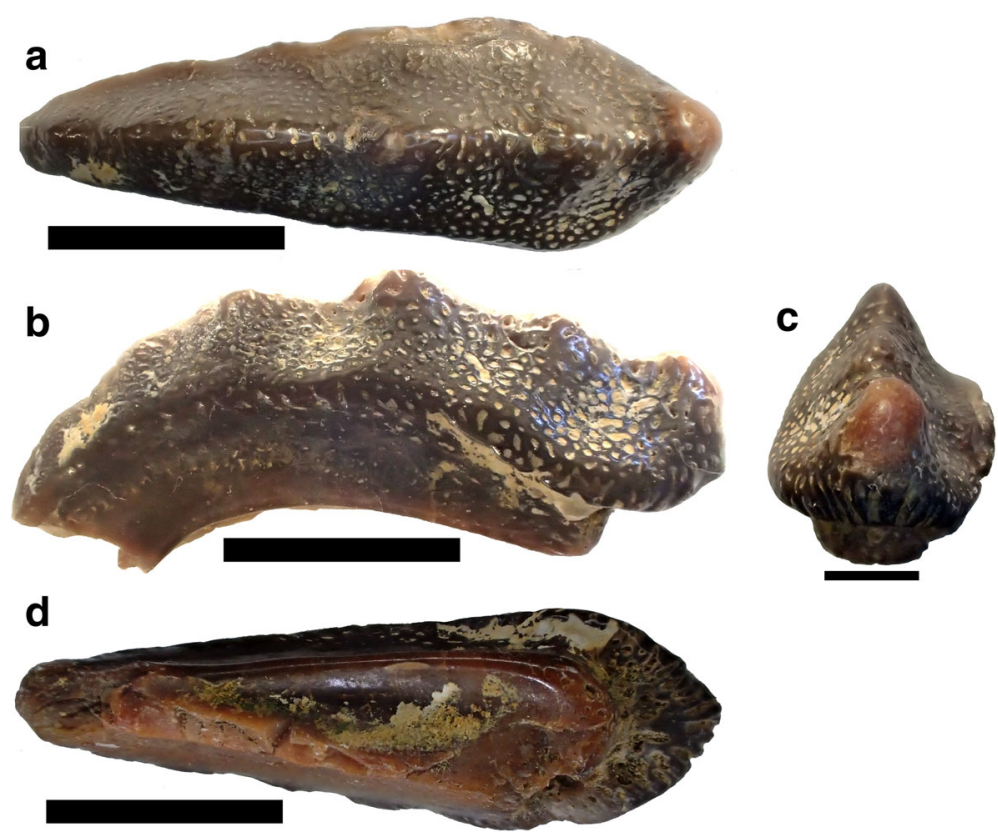

Fig. 9 Holotype of Arcuodus multicuspidatus. a Occlusal view. Lingual end to right. Scale bar $=5 \mathrm{~mm}$. b Lateral view. Lingual end to right. Scale bar $=5 \mathrm{~mm}$. c Lingual view. Scale bar $=2 \mathrm{~mm}$. d Basal view. Lingual end to right. Scale bar $=5 \mathrm{~mm}$ 
1906. Deltodopsis? bialveatus; Branson [32], p. 1391, pl. 41, figs. 8-9

1999. Deltodus affinis; Stahl [2], pp. 70-71, fig. 67A

Holotype

A tooth plate, USNM V13017.

\section{Referred specimens}

Tooth plates, AMNH FF6450, USNM V13015, USNM V13016.

\section{Occurrence}

Burlington Limestone, Louisa County, IA, USA; Keokuk Limestone, Warsaw, IL, USA; Salem Limestone, Lanesville, IN, USA. Mississippian, Osagean to Meramecian = late Tournaisian to Viséan.

\section{Emended diagnosis}

Species of Arcuodus having tooth plates in which occlusal surface is more or less smooth and convex, never sharply ridged with cusps as in Arcuodus multicuspidatus. Degree of symmetry with regard to the labiolingual axis varies from nearly bilaterally symmetric to moderately asymmetric.

\section{Remarks}

St. John and Worthen [31] defined three species based on small, narrow, tooth plates, referred with some uncertainty to Deltodopsis, as Deltodopsis? bialveatus, Deltodopsis? keokuk, and Deltodopsis? convexus. In defining the three species, based on tooth plates with differing morphologies, they expressed uncertainty as to whether the specimens represented different species or merely varieties. To this uncertainty should be added the positional uncertainty, i.e., whether the tooth plates are mandibular or maxillary and their precise position within either jaw. The high degree of symmetry of USNM V13015 (Fig. 10a) suggests that it may have occupied a symphyseal position. The other specimens are asymmetric, suggesting that they may have occupied a non-symphyseal anterior position. Given the present state of knowledge, the separation of D.? keokuk and D.? convexus from D.? bialveatus would be unjustified. Hence, we refer them both to Arcuodus bialveatus, comb. nov. In contrast to the specimens of D.? bialveatus and D.? convexus figured by St. John and Worthen [31], the type specimen of D.? keokuk does not appear to be in the USNM collections. Its whereabouts are currently unknown. On the caption to fig. 67A, Stahl [2] referred the holotype of Deltodopsis? bialveatus, USNM 13017, to Deltodus affinis, but without any justification. Hence, that assignment is not recognized here. The basal structure of $A$. bialveatus, narrowing basally and with a concave basal surface (Figs. $7 \mathrm{~b}-\mathrm{c}$ ), is very similar to that
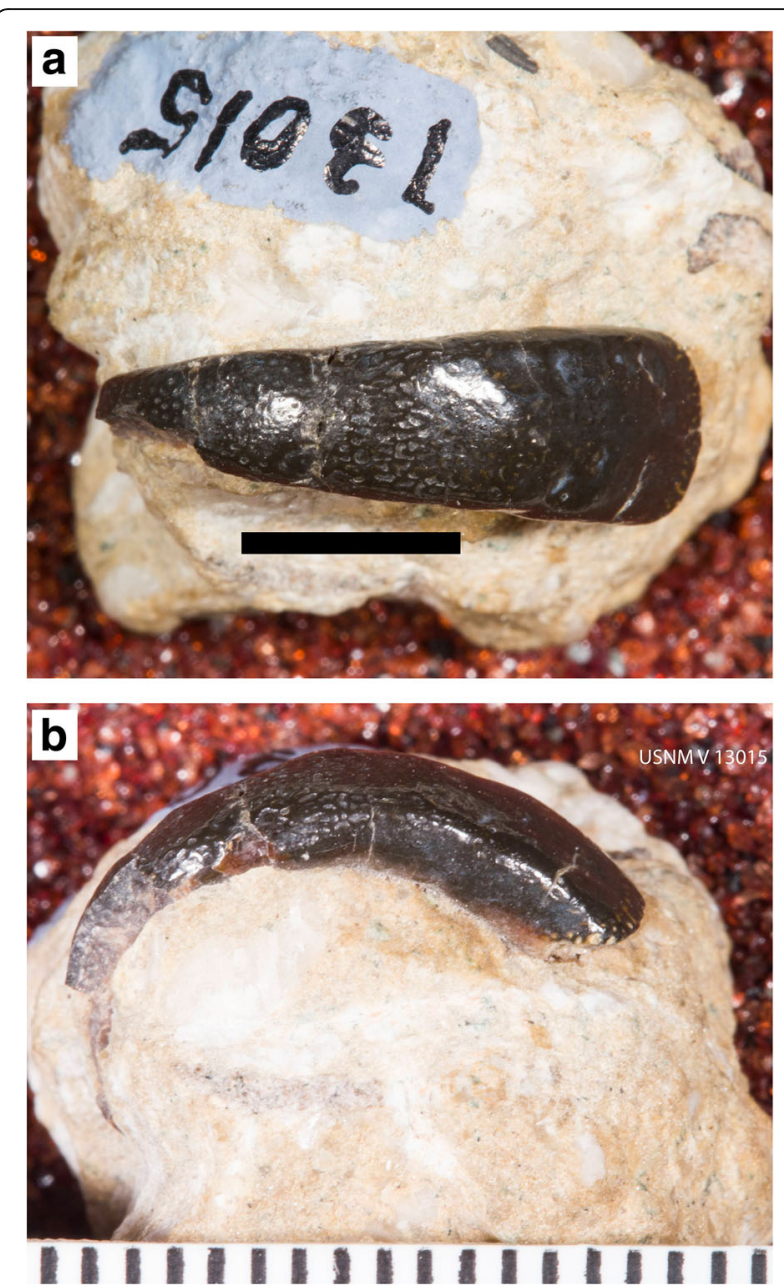

Fig. 10 Syntype of Deltodopsis? convexus, USNM V13015. Here designated as Arcuodus bialveatus, comb. nov. a Occlusal view. Lingual end to right. Scale bar $=5 \mathrm{~mm}$. $\mathbf{b}$ Lateral view. Lingual end to right. Millimeters scale divisions. Drawings of this specimen were published as St. John and Worthen, 1883 ([31], pl. 11, fig. 17). Images copyrighted, Smithsonian Institution, all rights reserved

of A. multicuspidatus (Fig. 9b, d). The occlusal surface of $A$. bialveatus, in contrast to that of A. multicuspidatus, lacks sharp cusps, but has shallow undulations which vary from closely spaced (Fig. 7a), to widely spaced (Fig. 10a), to not easily discernable (Fig. 6).

\section{Discussion}

\section{Anterior dentitions}

Anterior dentitions in holocephalians are poorly known and not easy to recognize when found isolated. The near-perfect bilateral symmetry of the holotype of $A$. multicuspidatus suggests that it occupied a symphyseal (Fig. 11a) or parasymphyseal (Fig. 11b) position at the anterior end of the jaw. Figure 11a and b show the tooth plate oriented with the wider end lingual and the narrow end labial. This is the orientation that is to be expected 

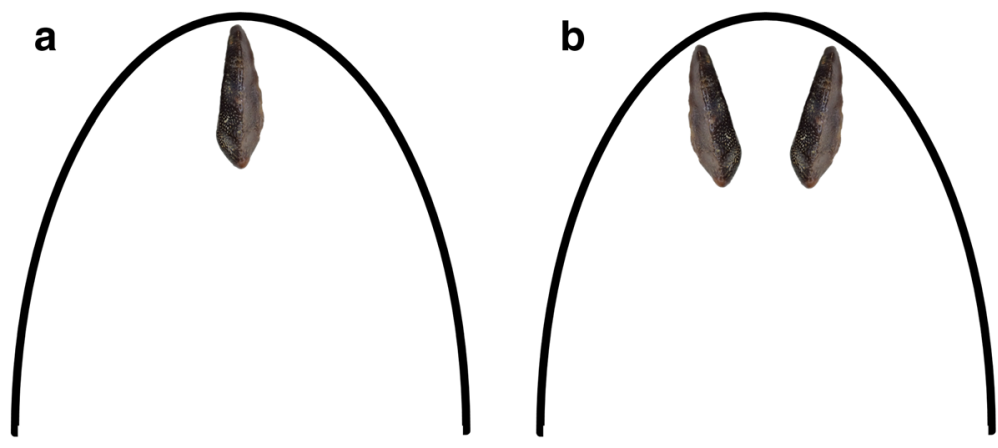

Fig. 11 Position of Arcuodus multicuspidatus tooth plate if (a) symphyseal, (b) parasymphyseal

if growth is at the lingual end (e.g., lyodont growth) as has been established for other tooth plates [33].

Symphyseal tooth plates are unknown in extant, Cenozoic, or Mesozoic chimaeroids. A symphyseal tooth plate is present in the Mesozoic holocephalian Myriacanthus paradoxus [2]. As has already been noted, $H$. volsellorhinus has a symphyseal tooth plate. In cases where the tooth plates appear to be bilaterally symmetric, their position can reasonably be inferred to be symphyseal, even when they are found isolated. Examples are some specimens of $P$. rankinei (Fig. 3), the holotype of A. multicuspidatus (Fig. 9a), and the syntype of Deltodopsis? convexus (Fig. 10a), here referred to Arcuodus bialveatus.

\section{Function of anterior dentitions}

Anterior tooth plates might have served to grasp prey, which would be crushed with the larger posterior tooth plates. The multiple nodes on the occlusal surfaces of the holotype of $A$. multicuspidatus or on the anterior tooth plates of $H$. volsellorhinus may have facilitated such a function. An analogy could be made with the extant shark Heterodontus, which has files of small, sharp anterior teeth and large, blunt posterior teeth.

\section{Origin of tooth plates from tooth files}

With regard to the evolution of tooth plates from tooth files, it is interesting to compare the tooth whorl that is the holotype of Helodus coxanus (Fig. 12) with A. multicuspidatus. In $H$. coxanus, the crowns are separate, although the bases appear to be fused. Being bilaterally symmetric, it has always been presumed to have occupied a symphyseal position [34]. The multiple pointed crowns could have been used to grasp prey, similarly to the anterior tooth files of Heterodontus. It seems probable that $A$. multicuspidatus was descended from an ancestor having a tooth whorl like that of $H$. coxanus. This does not imply actual descent of $A$. multicuspidatus from $H$. coxanus, nor of $A$. bialveatus from A. multicuspidatus. The tooth file of Helodus coxanus and the tooth plates of A. multicuspidatus and of A. bialveatus form a morphological series, but, given the present state of knowledge, it is impossible to know whether or not they form a phylogenetic series. The transition from tooth files to tooth plates very likely occurred independently in several different lineages. The transition from tooth files to tooth plates within the Helodontiformes (e.g., from Helodus simplex to Pleuroplax rankinei) was most likely independent of the transition, probably within the
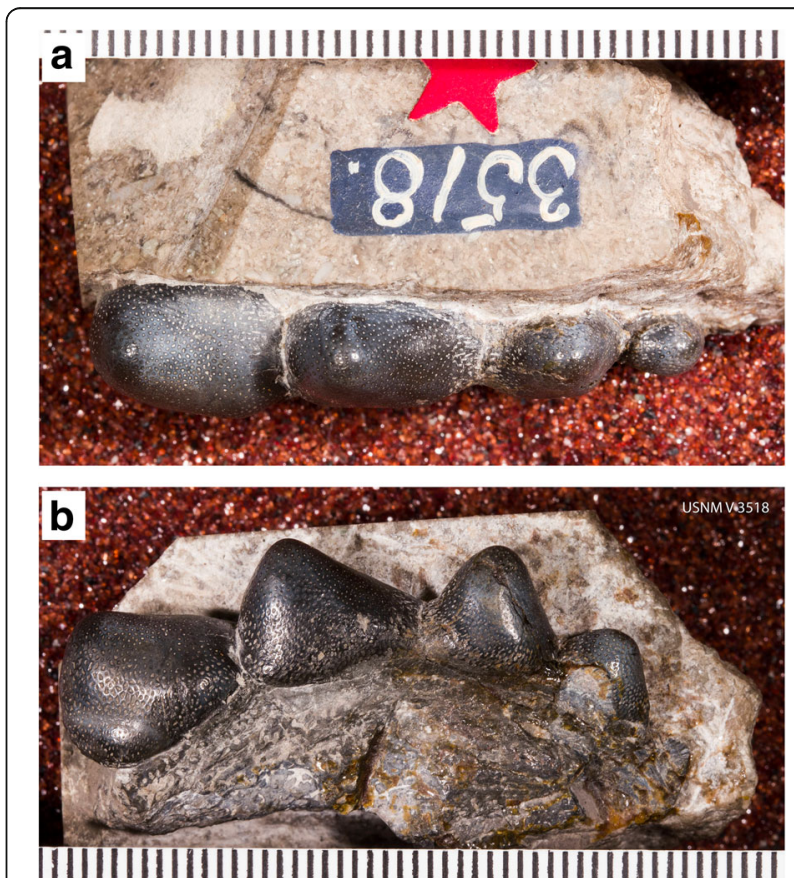

Fig. 12 Holotype of Helodus coxanus Newberry, 1897, USNM V3518. a Occlusal view. Lingual end to left. Millimeter scale divisions. b Lateral view. Lingual end to left. Millimeter scale divisions. A drawing of this specimen was published as Newberry, 1897 ([34], pl. 24, fig. 24). Images copyrighted, Smithsonian Institution, all rights reserved 
Cochliodontiformes, that resulted in the tooth plate of Arcuodus multicuspidatus.

Helodus coxanus was chosen for the comparison because, compared to other, broadly similar tooth files, such as that of Helodus simplex (Fig. 2) or of Helodus appendiculatus (e.g., NHMUK PV P2916), the relative dimensions of the tooth file are similar to those of the tooth plates here included in Arcuodus. The crowns of both $H$. simplex and $H$. appendiculatus are much wider mesio-distally than linguo-labially. Those of $H$. coxanus are much more compressed mesio-distally, so that the overall shape of the tooth file matches that of the tooth plate of $A$. multicuspidatus rather closely. The comparison of A. multicuspidatus and $A$. bialveatus is natural, since the two taxa are so close morphologically that they have been assigned to the same genus.

The generic assignment of Helodus coxanus deserves some comment. Helodus simplex is the type species of Helodus and is also known from articulated specimens [19]. All other species of Helodus are founded on isolated teeth, many of which probably should be referred to other genera. Many, if not most, of these are anterior teeth of other chondrichthyan fishes, which are known from other remains, such as tooth plates. Until articulated remains are found, there seems to be no way to determine which teeth and tooth plates belong to the same species. Unlike the situation for A. multicuspidatus and A. bialveatus, no close relationship between $H$. coxanus and $H$. simplex is implied by the fact that they are currently assigned the same genus name.
Table 1 summarizes information regarding taxonomy, age, and morphology for the most important specimens discussed here. Since the ages are for individual specimens, the age ranges for the taxa are unknown, and chondrichthyan species can have rather long age ranges. Because the classifications of the listed taxa are imprecise, the conclusions that can be made as to evolutionary trends are very limited.

\section{Conclusions}

The new tooth plate from the Bangor Limestone of Alabama, USA, is referred to a new genus and species, Arcuodus multicuspidatus. The holotype and only known specimen is interpreted as having occupied an anterior position. The multicusped morphology of the tooth plate suggests that it might have had a grasping function. The multiple cusps suggest that $A$. multicuspidatus might have evolved from a fish having a tooth file like that of Helodus coxanus, having separate teeth. A. bialveatus, which possesses a tooth plate that lacks prominent cusps, may have evolved from a fish possessing a tooth plate similar to that of $A$. multicuspidatus. The age of A. multicuspidatus is middle to latest Chesterian (Serpukhovian). Several other tooth plates questionably referred to Deltodopsis by St. John and Worthen are referred to Arcuodus bialveatus comb. nov. The dentitions of the three taxa: Helodus coxanus, Arcuodus multicuspidatus, and Arcuodus bialveatus form a morphological sequence. Whether they also form a phylogenetic sequence is not possible to determine with the present evidence.

Table 1 Key specimens with taxonomy, ages, and features

\begin{tabular}{|c|c|c|c|c|c|c|}
\hline Specimen & Fig. & Original designation & Current designation & Taxonomic group & Age & Features \\
\hline NHMUK PV P8216 & 2 & Helodus simplex & Helodus simplex & Helodontidae & Pennsylvanian & $\begin{array}{l}\text { Tooth file, teeth mesiodistallly } \\
\text { expanded and bilaterally } \\
\text { symmetric or nearly so }\end{array}$ \\
\hline NHMUK PV P1415 & 3 & Pleurodus rankinii & Pleuroplax rankinei & Helodontidae & Pennsylvanian & $\begin{array}{l}\text { Tooth plate with crenulated } \\
\text { edges, bilaterally symmetric }\end{array}$ \\
\hline USNM V3518 & 12 & Helodus coxanus & Helodus coxanus & Cochliodontiformes? & $\begin{array}{l}\text { Mississippian } \\
\text { (early Viséan) }\end{array}$ & $\begin{array}{l}\text { Tooth file, crowns triangular, } \\
\text { mesiodistally compressed, bases } \\
\text { fused, bilaterally symmetric }\end{array}$ \\
\hline $\begin{array}{l}\text { ALMNH PV } \\
\text { 2016.0002.0002 }\end{array}$ & 9 & $\begin{array}{l}\text { Arcuodus } \\
\text { multicuspidatus }\end{array}$ & $\begin{array}{l}\text { Arcuodus } \\
\text { multicuspidatus }\end{array}$ & Cochliodontiformes & $\begin{array}{l}\text { Mississippian } \\
\text { (late Serpukhovian) }\end{array}$ & $\begin{array}{l}\text { Tooth plate with sharp median } \\
\text { ridge, sharp cusps, bilaterally } \\
\text { symmetric or nearly so }\end{array}$ \\
\hline USNM V13017 & 6 & Deltodopsis? bialveatus & Arcuodus bialveatus & Cochliodontiformes & $\begin{array}{l}\text { Mississippian } \\
\text { (late Tournasian) }\end{array}$ & $\begin{array}{l}\text { Tooth plate with low, irregular } \\
\text { bulges, not bilaterally symmetric }\end{array}$ \\
\hline AMNH FF6450 & 7 & Deltodopsis? bialveatus & Arcuodus bialveatus & Cochliodontiformes & $\begin{array}{l}\text { Mississippian } \\
\text { (early Viséan) }\end{array}$ & $\begin{array}{l}\text { Tooth plate with low, wide, } \\
\text { transverse ridges, not bilaterally } \\
\text { symmetric }\end{array}$ \\
\hline USNM V13015 & 10 & Deltodopsis? convexus & Arcuodus bialveatus & Cochliodontiformes & $\begin{array}{l}\text { Mississippian } \\
\text { (late Tournasian) }\end{array}$ & $\begin{array}{l}\text { Tooth plate with very low } \\
\text { surface undulations, bilaterally } \\
\text { symmetric or nearly so }\end{array}$ \\
\hline
\end{tabular}




\section{Abbreviations}

ALMNH: Alabama Museum of Natural History, Tuscaloosa, AL, USA; AMNH: American Museum of Natural History, New York, NY, USA; NHMUK: Natural History Museum, London, UK; USNM: National Museum of Natural History, Washington, DC, USA

\section{Acknowledgments}

We thank Larry White for finding the holotype of A. multicuspidatus and for collecting the matrix for conodont sampling, Dana Ehret and Mary Beth Prondzinski for repositing the specimen at the University of Alabama Museum, Chris Duffin, Michał Ginter, Oleg Lebedev, Gilles Cuny, Michael Hansen, and Tim Smithson for their help in identification of the specimen, Amanda Millhouse and Michael Brett-Surman (USNM) for photographs of specimens, Martha Richter (NHMUK) and John Maisey and Alana Gishlick (AMNH) for access to specimens, and Janet Vote, Jessica Rossler, and Jeffrey Hardwick for assistance with conodont processing and picking. We thank the Associate Editor and two anonymous reviewers for their comments, which resulted in greatly improving the manuscript, particularly in regard to the discussion of the origin of tooth plates from tooth files.

\section{Availability of data and materials}

All specimens and locality data are reposited at the institutions listed. All other data are in the text and figures of the article.

\section{Authors' contributions}

LLL processed the limestone matrix from the Bangor Formation for conodonts, interpreted the conodont data, and wrote the sections of the manuscript on the conodont biostratigraphy and the paleoenvironment of the Bangor Limestone. WMI prepared the holotype of A. multicuspidatus, examined comparative material at the $\mathrm{AMNH}$ and $\mathrm{NHMUK}$, and prepared the rest of the manuscript. Both authors read and approved the final manuscript.

\section{Ethics approval and consent to participate}

Not applicable

\section{Competing interests}

The authors declare that they have no competing interests.

\section{Publisher's Note}

Springer Nature remains neutral with regard to jurisdictional claims in published maps and institutional affiliations.

\section{Author details}

1 Museum of Natural History, University of Colorado, Boulder, CO 80309, USA.

2University of Texas at San Antonio, San Antonio, TX 78249, USA.

\section{Received: 10 December 2017 Accepted: 11 May 2018}

Published online: 06 June 2018

\section{References}

1. Didier DA, Stahl BJ, Zangerl R. Development and growth of compound tooth plates in Callorhinchus milii (Chondrichthyes, Holocephali). J Morphol. 1994:222:73-89.

2. Stahl BJ. Chondrichthyes III. Holocephali. In: Schultze H-P, editor. Handbook of Paleoichthyology 4. Munich: Verlag Dr. Friedrich Pfeil; 1999. p. 1-164.

3. Smith MM, Johanson Z, Underwood C, Diekwisch TGH. Pattern formation in development of chondrichthyan dentitions: a review of an evolutionary model. Hist Biol. 2013;25:127-42.

4. Rasch $\sqcup$, Martin KJ, Cooper RL, Metscher BD, Underwood CJ. An ancient dental gene set governs development and continuous regeneration of teeth in sharks. Dev Biol. 2016:415:347-70.

5. Underwood CJ, Johanson Z, Welton M, Metscher B, Rasch LJ, Fraser GJ, Smith MM. Development and evolution of dentition pattern and tooth order in the skates and rays (Batoidea; Chondrichthyes). PLoS One. 2015;10: e0122553.

6. Maisey JG, Turner S, Naylor GJP, Miller RF. Dental patterning in the earliest sharks: implications for tooth evolution. J Morphol. 2014;275:586-96.

7. Inoue JG, Miya M, Lam K, Tay B-H, Danks JA, Bell J, Walker TI, Venkatesh B. Evolutionary origin and phylogeny of the modern holocephalans (Chondrichthyes: Chimaeraformes): a mitogenomic perspective. Mol Bio Evol. 2010;27:2576-86.
8. Pradel A, Tafforeau P, Maisey JG, Janvier P. A new Paleozoic Symmoriiformes (Chondrichthyes) from the Late Carboniferous of Kansas (USA) and cladistic analysis of early chondrichthyans. PLoS One. 2011;6:e24938.

9. Coates MI, Gess RW, Finarelli JA, Criswell KE, Tietjen K. A symmoriiform chondrichthyan braincase and the origin of chimaeroid fishes. Nature. 2017; 541:208-11.

10. Itano WM, Lambert LL. A new holocephalan tooth plate from the Bangor Limestone (Mississippian, Chesterian) of northern Alabama. In: Geological Society of America Annual Meeting Abstracts; 2016.

11. Ciampaglio C, Deuter LH, Taylor MA, Cicimurri DJ. A review of the chondrichthyans from the Mississippi system of northern Alabama, USA. Bull Ala Mus Nat Hist. 2012;28:67-80.

12. Patterson C. Menaspis and the bradyodonts. In: Ørvig T, editor. Current problems of lower vertebrate phylogeny. Stockholm: Almqvist and Wiksell; 1968. p. 171-205.

13. Stahl BJ, Hansen MC. Dentition of Deltodus angularis (Holocephali, Cochliodontidae) inferred from associated tooth plates. Copeia. 2000;2000:1090-6.

14. Lund R. Harpagofututor volsellorhinus new genus and species (Chondrichthyes, Chondrenchelyiformes) from the Namurian Bear Gulch Limestone, Chondrenchelys problematica Traquair (Viséan), and their sexual dimorphism. J Paleontol. 1982;56:938-58.

15. Gradstein FM, Ogg JG, Schmitz MD, Ogg GM. The geologic time scale 2012. Vol. 2. Amsterdam: Elsevier; 2012

16. Finarelli JA, Coates MI. First tooth-set outside the jaws in a vertebrate. Proc R Soc B. 2012:279:775-9.

17. Finarelli JA, Coates MI. Chondrenchelys problematica (Traquair, 1888) redescribed: a Lower Carboniferous, eel-like holocephalan from Scotland. Earth Environ Sci Trans R Soc Edinb. 2014;105:35-59.

18. Agassiz L. Recherches sur les poissons fossiles, vol. 3. Neuchâtel: Petitpierre; 1833-1843.

19. Moy-Thomas JA. On the structure and affinities of the Carboniferous cochliodont Helodus simplex. Geol Mag. 1936;73:488-503.

20. Hancock A, Atthey T. Descriptive note on a nearly entire specimen of Pleurodus Rankinii, on two new species of Platysomus and a new Amphicentrum, with remarks on a few other fish-remains found in the Coalmeasures of Newsham. Ann Mag Nat Hist. 1872:9:249-62

21. Brasier MD. Microfossils. London: George Allen and Unwin; 1980.

22. Drahovzal JA. The biostratigraphy of Mississippian rocks in the Tennessee Valley. In: Smith WE, editor. A guidebook for the fifth annual field trip of the Alabama Geological Society, Alabama Geological Society; 1967. p. 10-24.

23. Thomas WA. Mississippian stratigraphy of Alabama. Geological Surv Ala Monogr. 1972;12:1-121.

24. Henry TW, Gordon M Jr, Schweinfurth SP, Gillespie WH. Significance of the goniatite Bilinguites eliasi and associated biotas, Parkwood Formation and Bangor Limestone, northwestern Alabama. J Paleontol. 1985:59:1138-45.

25. Szabo EW, Osbourne WE, Copeland CW Jr, Neathery TL. Geologic map of Alabama, Geological Survey of Alabama Special Map 220. Capitol Heights: William and Heintz Map Corporation; 1988.

26. Abplanalp JM, Isaacson PE, Batt LS, Pope MC. Conodont biostratigraphy of Chesterian strata (Late Mississippian - Early Pennsylvanian), east-central Idaho and southwestern Montana. Mt Geol. 2009:46:89-104.

27. Huxley TH. On the application of the laws of evolution to the arrangement of the Vertebrata, and more particularly of the Mammalia. Proc Sci Meet Zoolog Soc London. 1880;1880:649-62.

28. Lund R, Grogan ED. Relationships of the Chimaeriformes and the basal radiation of the Chondrichthyes. Rev Fish Biol Fish. 1997;7:65-123.

29. Bonaparte CL. Selachorum tabula analytica. Nuovi Annali delle Scienze Naturali Bologna. 1838:2:195-214.

30. Obruchev DV. Izuchenie edestid i raboty A. P. Karpinskogo [A study of the edestids and the work of A. P. Karpinskii]. Trudy Paleontologicheskogo Instituta Akademii Nauk SSSR [Transactions of the Palaeontological Institute]. 1953;45:1-85.

31. St. John O, Worthen AH. Descriptions of fossil fishes. Geological Surv III. 1883;7:55-264.

32. Branson EB. Fish remains from the Salem Limestone of Indiana. In: Blatchley WS, editor. 30th annual report of the Indiana Department of Geology and Natural Resources for 1905. Indianapolis: Wm. B. Burford; 1906. p. 1376-94.

33. Patterson C. Interpretation of the toothplates of chimaeroid fishes. Zool J Linnean Soc. 1992;106:33-61.

34. Newberry JS. New species and a new genus of American Palaeozoic fishes, together with notes on the genera Oracanthus, Dactylodus, Polyrhizodus, Sandalodus, Deltodus. Trans N Y Acad Sci. 1897;26:282-304. 